\title{
Steel fiber reinforced concrete pipes. Part 1: technological analysis of the mechanical behavior
}

\section{Tubos de concreto reforçado com fibras de aço. Parte 1: análise tecnológica do comportamento mecânico}
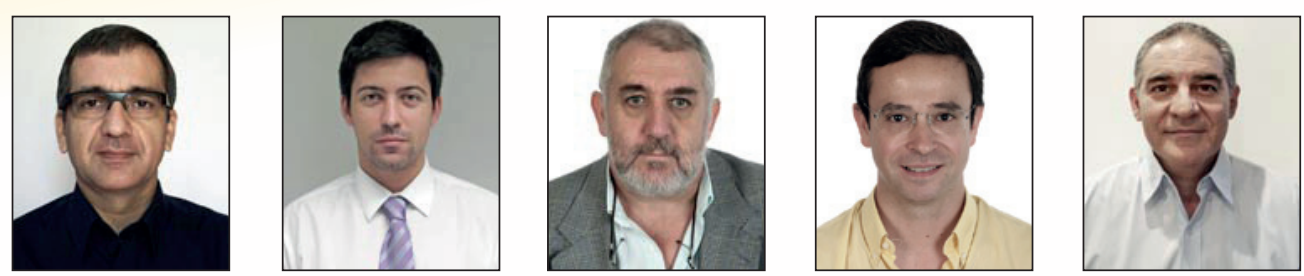

A. D. DE FIGUEIREDO a antonio.figueiredo@poli.usp.br

A. DE LA FUENTE albert.de.la.fuente@upc.edu

A. AGUADO ${ }^{\circ}$

antonio.aguado@upc.edu

C. MOLINS d climent.molins@upc.edu

P. J. CHAMA NETO pchama@sabesp.com.br

\section{Abstract}

This paper is the first part of an extensive work focusing the technological development of steel fiber reinforced concrete pipes (FRCP). Here is presented and discussed the experimental campaign focusing the test procedure and the mechanical behavior obtained for each of the dosages of fiber used. In the second part ("Steel fiber reinforced concrete pipes. Part 2: Numerical model to simulate the crushing test"), the aspects of FRCP numerical modeling are presented and analyzed using the same experimental results in order to be validated. This study was carried out trying to reduce some uncertainties related to FRCP performance and provide a better condition to the use of these components. In this respect, an experimental study was carried out using sewage concrete pipes in full scale as specimens. The diameter of the specimens was $600 \mathrm{~mm}$, and they had a length of $2500 \mathrm{~mm}$. The pipes were reinforced with traditional bars and different contents of steel fibers in order to compare their performance through the crushing test. Two test procedures were used in that sense. In the $1^{\text {st }}$ Series, the diameter displacement was monitored by the use of two LVDTs positioned at both extremities of the pipes. In the $2^{\text {nd }}$ Series, just one LVDT is positioned at the spigot. The results shown a more rigidity response of the pipe during tests when the displacements were measured at the enlarged section of the socket. The fiber reinforcement was very effective, especially when low level of displacement was imposed to the FRCP. At this condition, the steel fibers showed an equivalent performance to superior class pipes made with traditional reinforced. The fiber content of $40 \mathrm{~kg} / \mathrm{m} 3$ provided a hardening behavior for the FRCP, and could be considered as equivalent to the critical volume in this condition.

Keywords: concrete pipes, steel fibers, crushing test, mechanical behavior, standards.

\section{Resumo}

A primeira parte deste trabalho se concentra no desenvolvimento tecnológico de tubos de concreto reforçado com fibras (TCRF). São apresentados e discutidos os resultados obtidos em um estudo experimental focado no procedimento de ensaio e na resposta mecânica obtida para cada um dos teores de fibras utilizados nos tubos. Na segunda parte do trabalho ("Tubos de concreto reforçado com fibra de aço. Parte 2: Modelo numérico para simular o ensaio de compressão diametral"), se apresentam os aspectos associados à simulação numérica da resposta mecânica destes tubos. Este estudo foi levado a cabo com a finalidade de tentar reduzir algumas das incertezas relacionadas com o desempenho dos TCRF e proporcionar melhores condições para viabilizar o uso das fibras como elemento de reforço em tubos. Neste sentido, se realizou um trabalho experimental utilizando corpos-de-prova em escala real. O diâmetro destes tubos foi de $600 \mathrm{~mm}$ e seu comprimento de $2500 \mathrm{~mm}$. Alguns dos tubos foram reforçados com armaduras convencionais e outros apenas com fibras metálicas com a finalidade de comparar as diferentes respostas mecânicas no ensaio de três cutelos. Empregaram-se dois procedimentos: numa $1^{a}$ série, o deslocamento diametral foi medido por meio de LVDTs posicionados em ambas as extremidades dos tubos, enquanto que, na $2^{\mathrm{a}}$ série se mediu o deslocamento apenas na ponta dos tubos. Neste sentido, os resultados obtidos demonstraram que a avaliação da rigidez do sistema depende da forma de medida dos deslocamentos. Além disso, foi comprovado que o reforço de fibras metálicas era eficiente, especialmente para níveis de carga próximos às cargas de serviço. Para baixas deformações, os TCRF apresentaram um melhor desempenho em termos de resistência em comparação com os tubos de concreto armado convencional. Por último, se concluiu que o consumo de $40 \mathrm{~kg} / \mathrm{m} 3$ pode ser considerado o volume crítico de fibras, pois pode obter um encruamento para a resposta estrutural do tubo.

Palavras-chave: tubos de concreto, fibras de aço, ensaio de compressão diametral, normas.

Department of Construction Engineering, Barcelona Tech (UPC), albert.de.la.fuente@upc.edu, C/Jordi Girona Salgado, 1-3, 08034, Barcelona (Spain) Department of Civil Construction Engineering, University of São Paulo (USP), antonio.figueiredo@poli.usp.br. Caixa Postal 61548, CEP 05508-900. São Paulo (Brazil)

Department of Construction Engineering, Barcelona Tech (UPC), antonio.aguado@upc.edu, C/Jordi Girona Salgado, 1-3, 08034, Barcelona (Spain) Department of Construction Engineering, Barcelona Tech (UPC), climent.molins@upc.edu, C/Jordi Girona Salgado, 1-3, 08034, Barcelona (Spain)

Companhia de Saneamento Básico do Estado de São Paulo (SABESP), pchama@sabesp.com.br, São Paulo (Brasil). 


\section{Introduction}

There is a huge necessity for sewage collecting and treatment systems in underdevelopment countries. The concrete pipes can be considered as a very competitive and sustainable alternative in relation to competitors in the market (Viñolas et al. [1]). Brazil has an instrument to reduce the deficiency in this segment since publication of the standard ABNT NBR 8890 [2] that allow the use of steel fibers for concrete pipes reinforcement [3]. This standard is equivalent to the European norm NBN-EM 1916 [4]. Both standards allow the use of conventional reinforcement with steel bars also. The pipes must to be verified in terms of mechanical performance through the crushing test or threeedge bearing test, despite the type of reinforcement used (bars of fibers). However, the steel fibers reinforced concrete pipes (FRCP) are not regularly used in Brazil nowadays, although the Brazilian standard had been published in 2007. One of the main reasons for this situation is related to the doubts concerning the FRCP mechanical performance that still remain in the market segment. These difficulties are also associated with the lack of numerical models capable of predicting the behavior of the component accurately. In order to resolve these problems, an experimental study focusing on the behavioral assessment of concrete sewage pipes was carried out. This study compared the performance between the pipes reinforced with steel fibers (FRCP) and the pipes reinforced with cold drown stee bars. The results turn possible the comparative performance evaluation of FRCP and the steel bars reinforced concrete pipes (SBRCP), and also the validation of a proposed numerical model for prediction of the pipe behavior during the crushing strength (de la Fuente et al. [5]). In this study, the influence of changes in testing methodology in the response of the components was also evaluated.

\section{Methodology}

The mechanical performance of concrete pipes is regularly measured with the crushing test method as specified by the standards
ABNT NBR 8890 [2] and EN 1916 [4] (Figure [1]). These standards prescribe two different procedures for the qualification of pipes, one for SBRCP, and the other for FRCP.

In the case of SBRCP, the pipe is subjected to a continuous loading up to rupture in order to determine the proof and ultimate loads. The proof load $\left(\boldsymbol{F}_{c}\right)$ is defined as $0.67 \boldsymbol{F}_{n}$, and $\boldsymbol{F}_{n}$ is the minimum crushing load. The strength class is defined by the $\boldsymbol{F}_{c}$, and is acceptable to be equal to the crack load $\left(\boldsymbol{F}_{c r}\right)$, corresponding to a crack with an opening of $0.25 \mathrm{~mm}$ [2] or less than $0.3 \mathrm{~mm}$ [4] and length of $300 \mathrm{~mm}$ or more according to Brazilian [2] and European [4] standards, respectively. The ultimate load $\left(\boldsymbol{F}_{u}\right)$ is the maximum achieved during testing and shall be equal or greater than $\boldsymbol{F}_{n}$.

In the standard crushing test method for FRCP there is a cyclic loading [2 and 4]. The first cycle consists of loading the pipe until an equivalent level of the proof load of the SBRCP. At this moment, the load is maintained for one minute and the pipe is checked for evidence of any damage. The pipe is rejected if any crack or other damage is observed. Thus, it is required that $\boldsymbol{F}_{c r}$ shall be greater $\boldsymbol{F}_{c}$. Once approved at this stage, the loading of the pipe is continued until the maximum load $\left(\boldsymbol{F}_{u}\right)$. When the load start to decrease and reach the value of $95 \%$ of $\boldsymbol{F}_{u}$ it shall be release, finishing the first cycle of the test. On the second cycle of the test, the pipe is reloaded up to $F_{c}$ and held for one minute. The pipe has to withstand this post-peak proof load in order to be approved. The test procedure established by the European standard [4] is finished at this point. In the specific case of the Brazilian standard [2], the second cycle is continued increasing the loading up to the moment that the pipe reach the maximum measured post-peak load $\left(\boldsymbol{F}_{\text {max,pos }}\right)$. The $\boldsymbol{F}_{\text {max,pos }}$ shall be greater than $1.05 \boldsymbol{F}_{c}$, named minimum required post-peak load $\left(\boldsymbol{F}_{\text {min,pos }}\right)$.

Although there are different test procedures prescribed by the standards to verify pipes with varied types of reinforcement, the continuous test was used in this experimental program in order to evaluate all specimens under uniform conditions of

\section{Figure 1 - Front and side views of the configuration adopted for the crushing test of concrete pipes}

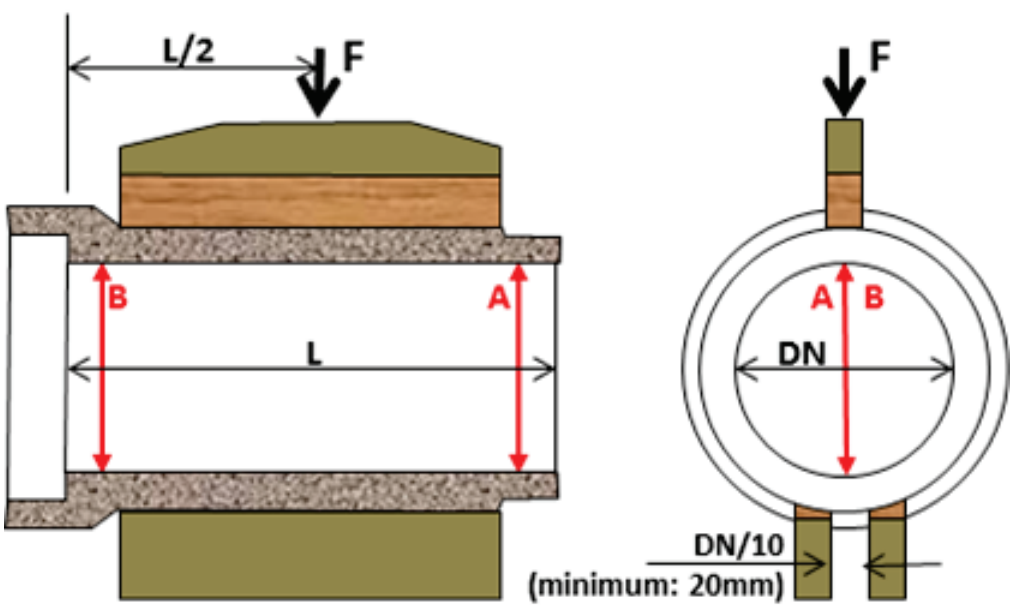




\section{Figure 2 - Configurations adopted for the measurement of displacements (A) at both extremities in the $1^{\text {st }}$ Series and (B) at the spigot for the $2^{\text {nd }}$ Series}

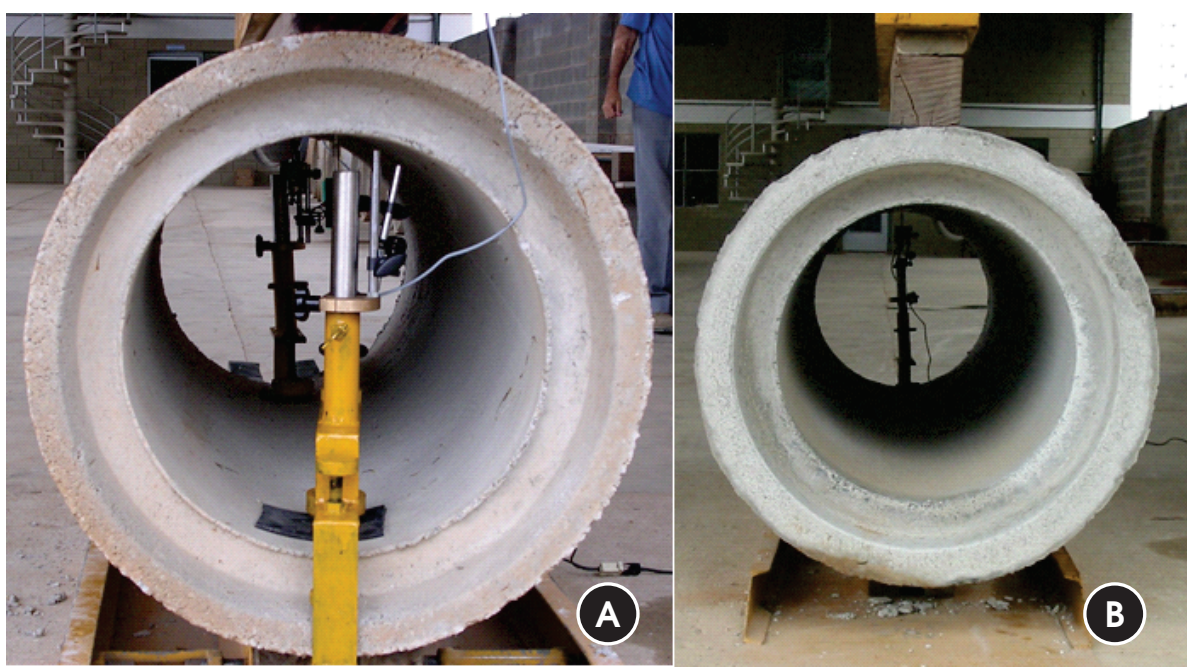

\section{Figure 3 - LVDT positioned at the upper part of the inner surface of the pipe}

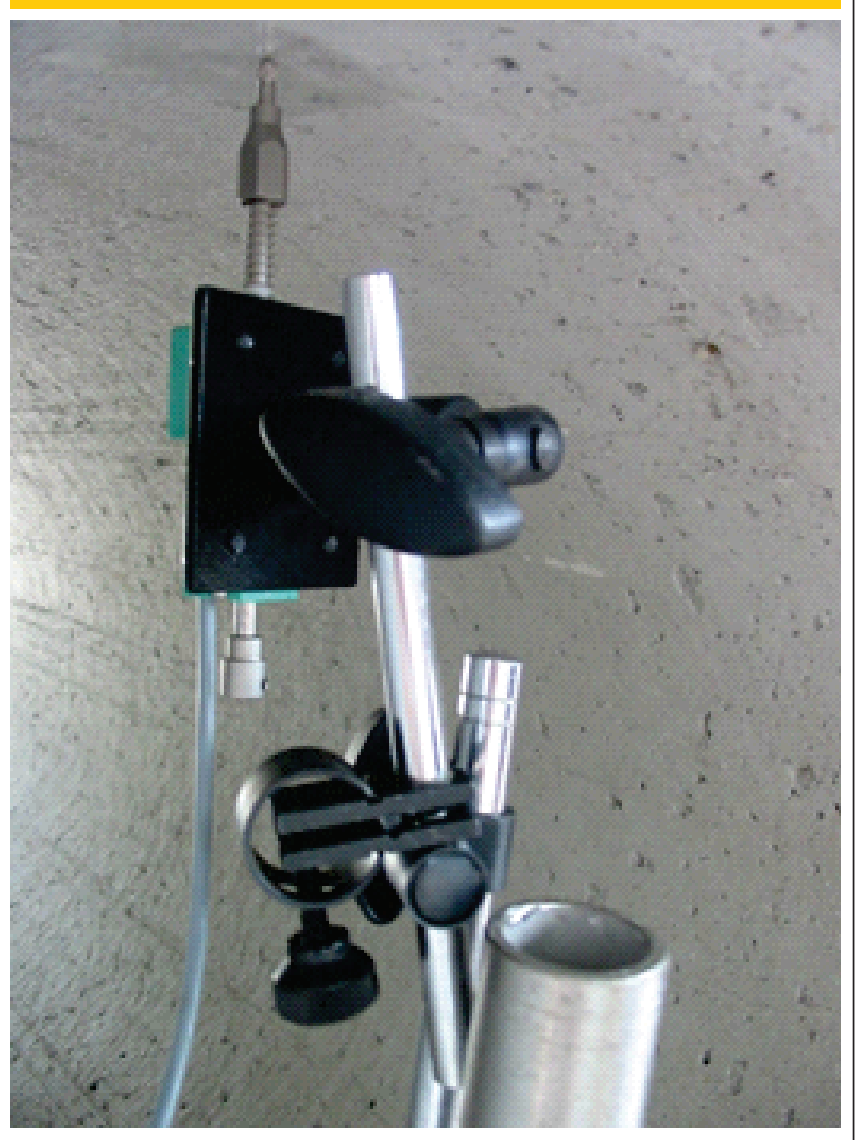

assessment. This solution was chosen because it was proven that there is no influence of number of cycles used in the test on the response of FRCP [6 and 7]. Devices were fixed to specimens providing a continuous acquisition of diametral displacement in order to improve the verification of pipes mechanical behavior during the tests. A similar test set up was used in previous studies [8 and 9]. This system consists of using LVDTs positioned against the upper part of the inner surface of the pipe and attached at supports fixed at the bottom part of the pipe as shown in Figures [2] and [3]. The set up used for LVDTs positioning allows the measurement of diametral displacements of the pipes without any interference of external strains or dislocations in the results.

This paper presents an experimental program broader than previously published by the same authors [10]. Two test configurations were used to measure the diametrical displacement of the pipes. At first one, the measurement of displacement occurred simultaneously at the spigot and the socket, corresponding to positions $A$ and $B$ (Figures [1] and [2a]). So, that situation turns possible to obtain the curve of load by average diametrical displacement of the pipes. In the second test configuration, only one LVDT was placed at position A, corresponding to the spigot of the pipe (Figures [1] and [2b]). Thus, two series of pipes were produced with fiber and conventional reinforcement to be tested with each of those test configurations.

Each series was produced in a single day in order to diminish the influence of intervening variables in the pipes production. In that sense, the same features and basic materials that were being regularly used by the company were applied for the pipes fabrication. The demanded amount of fiber was added directly on the aggregates conveyor belt. The rebars set up used is the same that had been routinely used by the factory (Figure [4]). Three levels of steel fibers consumptions $\left(10 \mathrm{~kg} / \mathrm{m}^{3}, 20 \mathrm{~kg} / \mathrm{m}^{3}\right.$ and $\left.40 \mathrm{~kg} / \mathrm{m}^{3}\right)$ were produced in each series together with three other SBRCP, totaling 24 pipes per series. 
Figure 4. Rebars set up used in SBRCP production that served as a parameter for comparative performance evaluation with FRCP. Some problems were observed molding the $1^{\text {st }}$ Series of pipes due to increased cohesion provided by the steel fibers. These problems were corrected in the $2^{\text {nd }}$ Series by adjusting the moisture of the mixture to maintain the fixed level of cohesion of the material. There was also changing the cement brand from first to $2^{\text {nd }}$ Series due to problems with suppliers. The materials used in this study and its consumption per cubic meter of concrete are presented in Table [1]. The steel fiber type used in the experiment was a glued hooked end drawn wire, $60 \mathrm{~mm}$ in length and diameter of $0.75 \mathrm{~mm}$. So, the aspect ratio of the fiber was 80 .

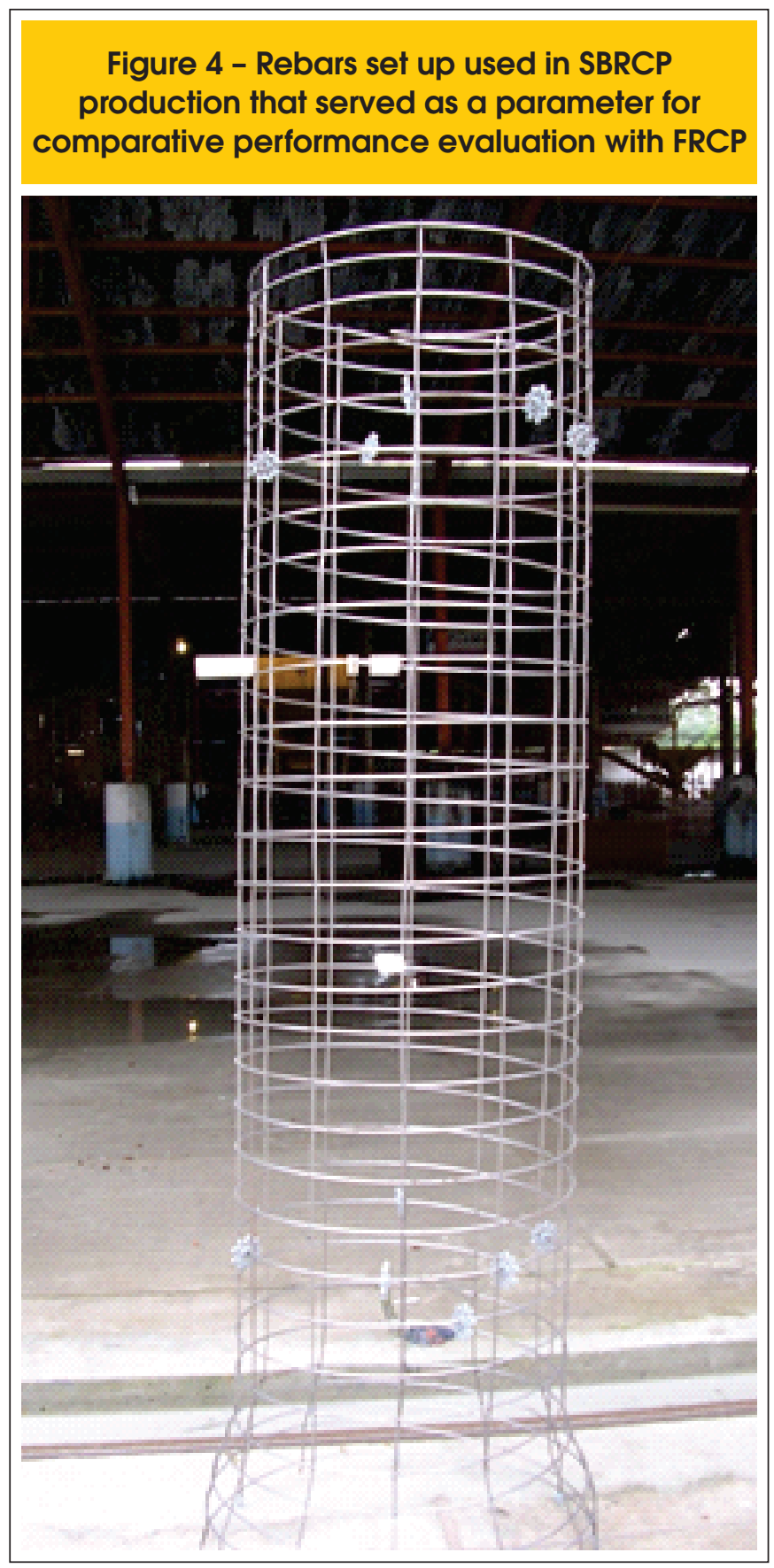

Table 1 - Material and its consumption per cubic meter of concrete used in the production of pipes used in this experimental study

\begin{tabular}{|cc|}
\hline Material & $\begin{array}{c}\text { Consumption } \\
\left(\mathrm{kg} / \mathrm{m}^{3}\right)\end{array}$ \\
\hline $\begin{array}{cc}\text { Fine aggregate I (Natural river sand) } \\
\text { Fine aggregate II (crushed sand) }\end{array}$ & 629 \\
Coarse aggregate (crushed stone) & 315 \\
Cement (CP III 40 RS) & 988 \\
Water** & 329 \\
\hline & 141 \\
\hline * A different brand of cement was used for each series of pipes. \\
** This amount of water was changed in the $2^{\text {nd }}$ Series \\
through visual analysis of the mixture in order to maintain \\
fixed the concrete consistency.
\end{tabular}

The main steel reinforcement (transverse reinforcement) was made with cold drawn steel bars (yield strength of $600 \mathrm{MPa}$ ) with a diameter of $6 \mathrm{~mm}$, and spaced each $85 \mathrm{~mm}$. The main reinforcement was positioned at the center of the pipe wall with equal distance for both inner and outer surface. A support reinforcement (longitudinal) made with 6 wires of the same type of steel was also used. The main reinforcement was positioned at the center of the pipe wall. The consumption of steel for this family of pipes was approximately $40 \mathrm{~kg} /$ $\mathrm{m}^{3}$. It was observed that the pipes produced with fibers presented a very good final finishing of the surface (Figure [5]), which reinforces the idea of the feasibility of its implementation.

After the production, the pipes remained in the storage yard of the factory until the moment of the crushing tests. All pipes were tested over the age of 28 days and at the same time. Other studies [11] found that there was no significant change in the behavior of reinforced concrete pipe in the hardened state when tested at ages ranging from 10 to 96 days. So, it was assured that there was no influence of age of the pipes in the results. The pipes were produced using the vibro-compression method with high speed (5000 $\mathrm{rpm}$ ) to compact the concrete. The geometric characteristics of the pipes are presented in Figure [6]. A summary of the differences between the two series is shown in Table [2].

\section{Results and Analysis}

The characteristic compressive strength of the concrete was 50 $\mathrm{MPa}$, obtained directly from the regular quality control results obtained by the factory. For each pipe, it was recorded the load versus displacement curve during the crushing test. The results obtained with the $1^{\text {st }}$ Series, where the average displacement was measured at the spigot and the socket simultaneously, are presented in Figures [7] to [10]. The results obtained with the measurement made only at the spigot, corresponding to the $2^{\text {nd }}$ Series, are presented in Figures [11] to [14]. In order to facilitate the comparison between the results, they are also presented in Figures [15] and [16] in terms of average curves obtained for the first and $2^{\text {nd }}$ Series, respectively. Only two results of the $1^{\text {st }}$ Series were lost 
Table 2 - Differences between the two series of pipes used in the experimental study

$\begin{array}{cccc}\text { Series } & \text { LVDT position } & \text { Cement } & \text { Water content } \\ \text { First } & \text { At the spigot and socket } & \text { Brand 1 } & \text { Fixed on } 141 \text { liters } / \mathrm{m}^{3} \\ \text { Second } & \text { Only at the spigot } & \text { Brand 2 } & \text { Adjusted for each mix (constant consistency) }\end{array}$

due to failures in the test system, where the reading of the strain was impaired. Because of that, only two curves are shown in Figures [7] and [8].

The fact that pipes have been tested in real scale caused a reduction of the results variability. In ordinary tests to determine the toughness of fiber reinforced concretes, the coefficient of variation can exceed $20 \%$ [12]. This occurs because the crack area (where the fibers act as a stress transfer bridge) is much larger in a tube than in a prismatic specimen. This reduction in variability has been observed in previous studies [7 and 13].

The first perceptible aspect was the behavior with a well defined pattern for pipes reinforced with smaller amounts of fiber. This softening pattern was characterized by a reduction of the strength of the pipe with increasing vertical displacement. The pipes reinforced with steel bars or $40 \mathrm{~kg} / \mathrm{m}^{3}$ of fibers had presented a

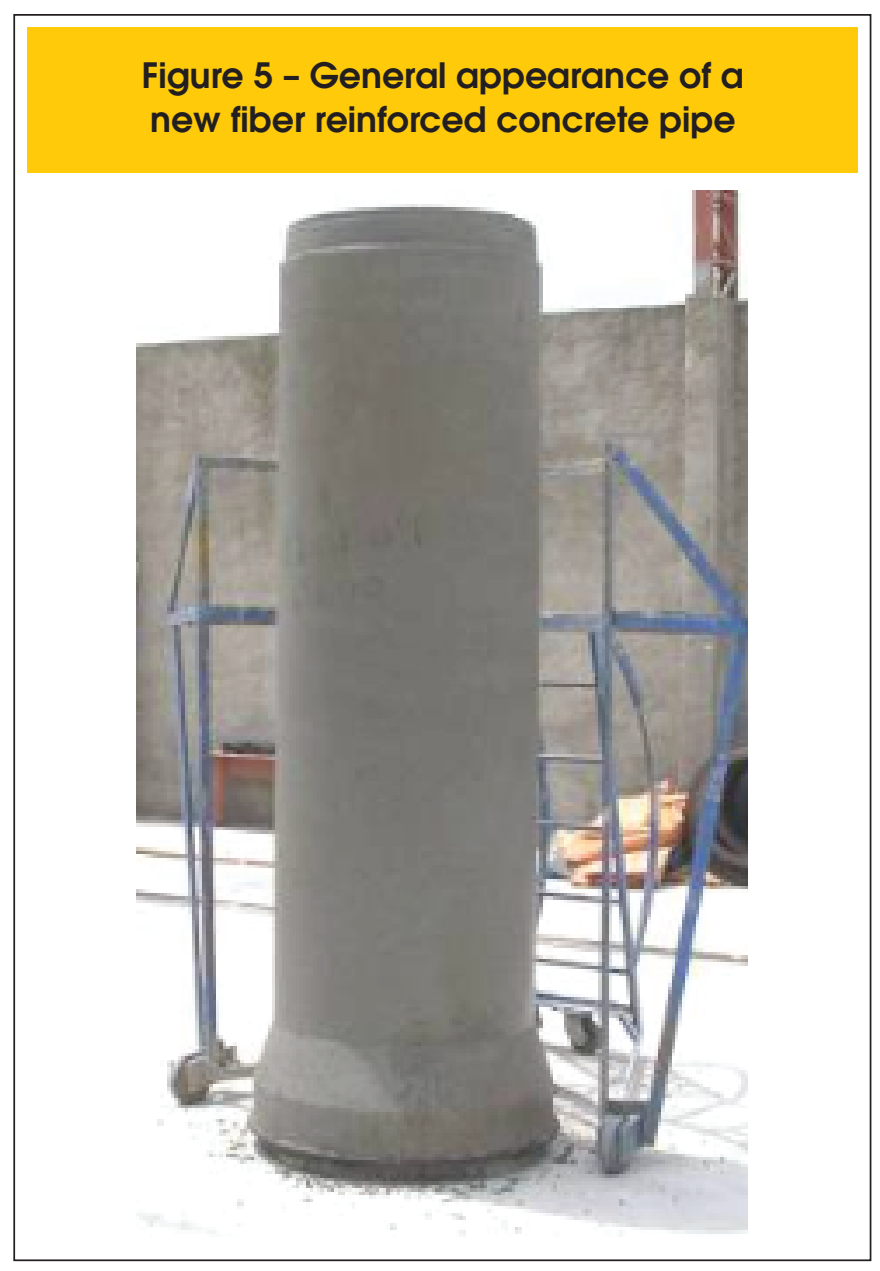

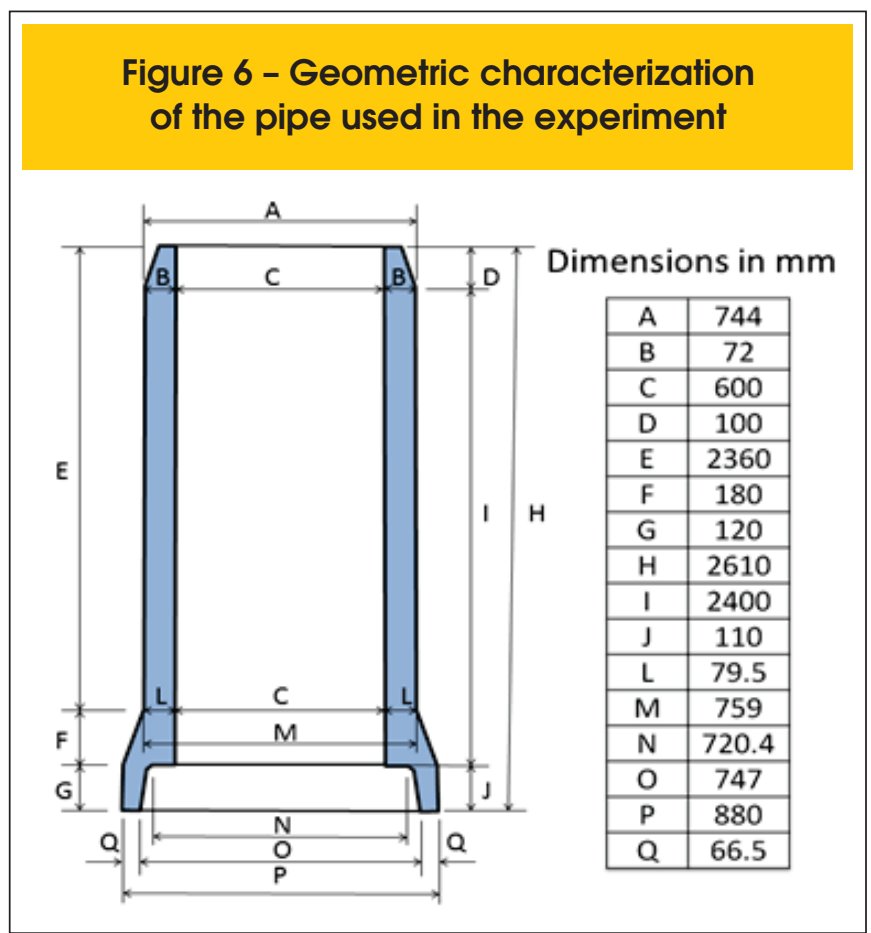

Figure 7 - Load versus displacement curves obtained during crushing test of pipes with a fiber consumption of $10 \mathrm{~kg} / \mathrm{m}^{3}$ and with the diametrical displacement measured at the spigot and the socket

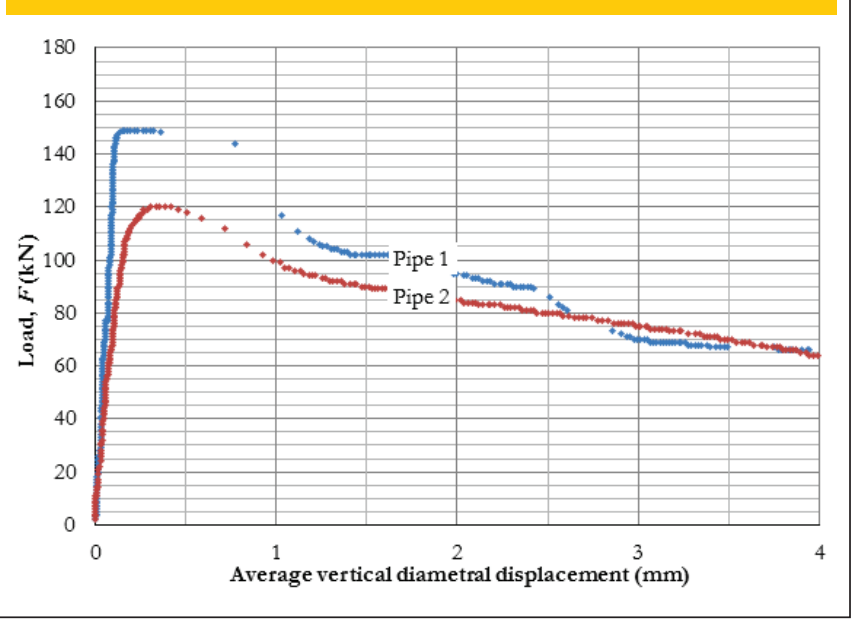


Figure 8 - Load versus displacement curves obtained during crushing test of pipes with a fiber consumption of $20 \mathrm{~kg} / \mathrm{m}^{3}$ and with the diametrical displacement measured at the spigot and the socket

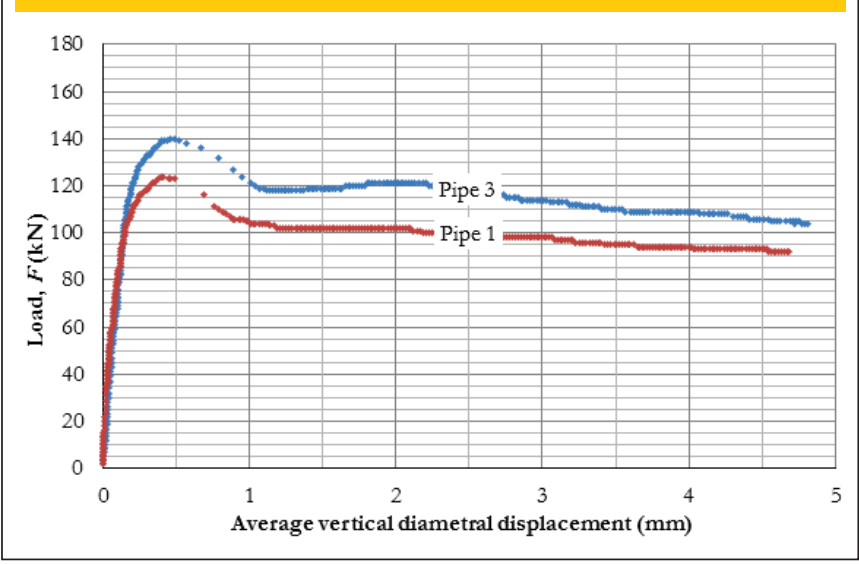

Figure 9 - Load versus displacement curves obtained during crushing test of pipes with a fiber consumption of $40 \mathrm{~kg} / \mathrm{m}^{3}$ and with the diametrical displacement measured at the spigot and the socket

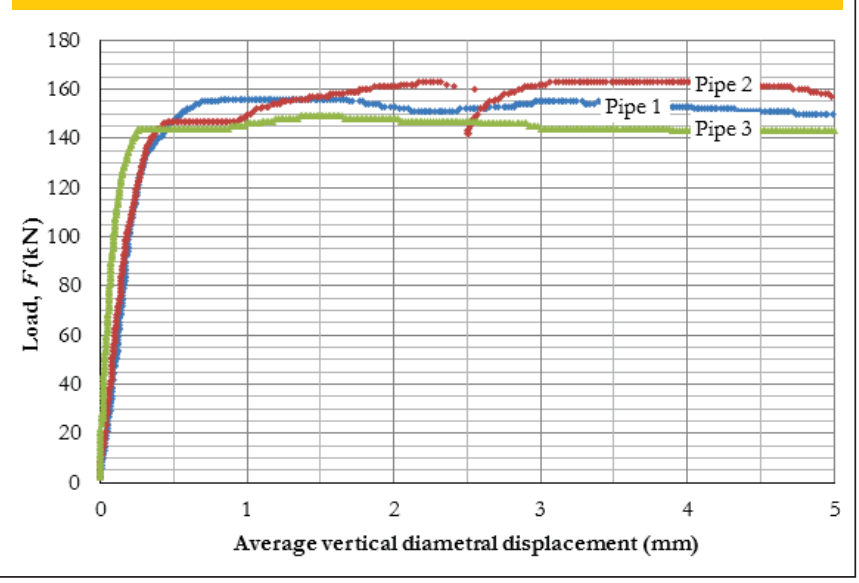

hardening pattern, which consists of increasing resisted load with increasing vertical displacement of the pipe. Thus, the resistance displayed by pipes with regular reinforcement was largest than the presented by FRCP at higher displacements. However, for lower strain, the residual strength capacity was greater for FRCP. This occurs because the bars are positioned at the innermost part of the pipe wall and they are mobilized more intensely when there is greater displacement and hence higher level of cracking. On the other hand, the fibers are distributed throughout the thickness of the pipe wall. Thus, the fibers reinforcement is mobilized with small levels of displacement and cracking, which provides better performance in this situation.
In order to facilitate the analysis of the influence of the setups for measuring displacements in the pipes during the crushing test the results of the average curves obtained with the greater fiber content are presented in Figure [17]. The results obtained in the $1^{\text {st }}$ Series, where the displacement measurements were made at the spigot and at the socket simultaneously, had presented higher stiffness in the beginning of the curve. The end of the initial elastic line was prolonged by the influence of the socket region where the concrete matrix contributes more intensely [14]. For the $2^{\text {nd }}$ Series, where the displacements were measured only at the spigot, they were more intense for smaller loads, due to lower rigidity of this part

Figure 10 - Load versus displacement curves obtained during crushing test of pipes with a conventional reinforcement and with the diametrical displacement measured at the spigot and the socket

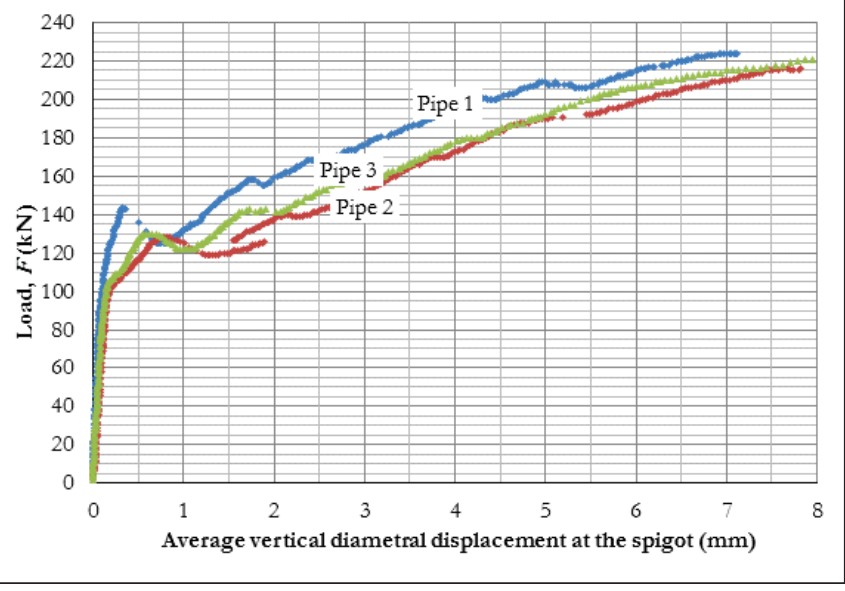

Figure 11 - Load versus displacement curves obtained during crushing test of pipes with a fiber consumption of $10 \mathrm{~kg} / \mathrm{m}^{3}$ and with the diametrical displacement measured only at the spigot

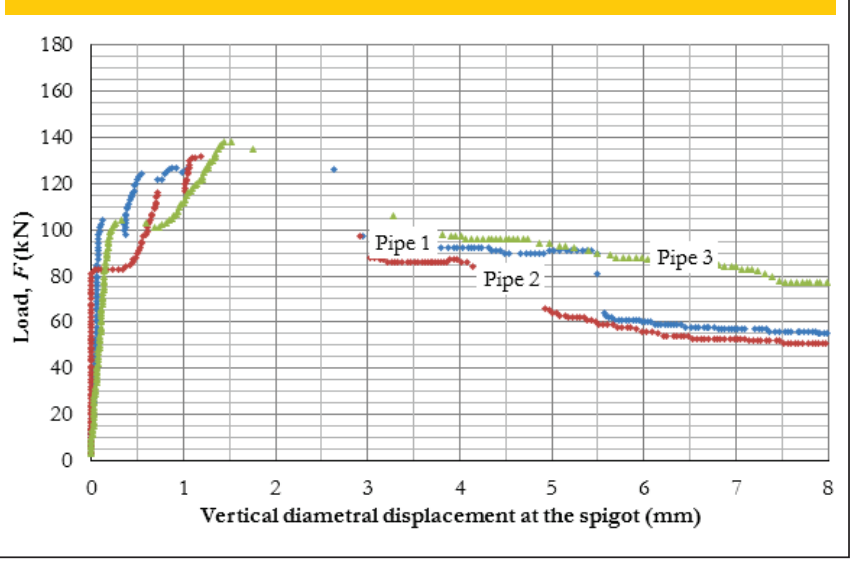


Figure 12 - Load versus displacement curves obtained during crushing test of pipes with a fiber consumption of $20 \mathrm{~kg} / \mathrm{m}^{3}$ and with the diametrical displacement measured only at the spigot

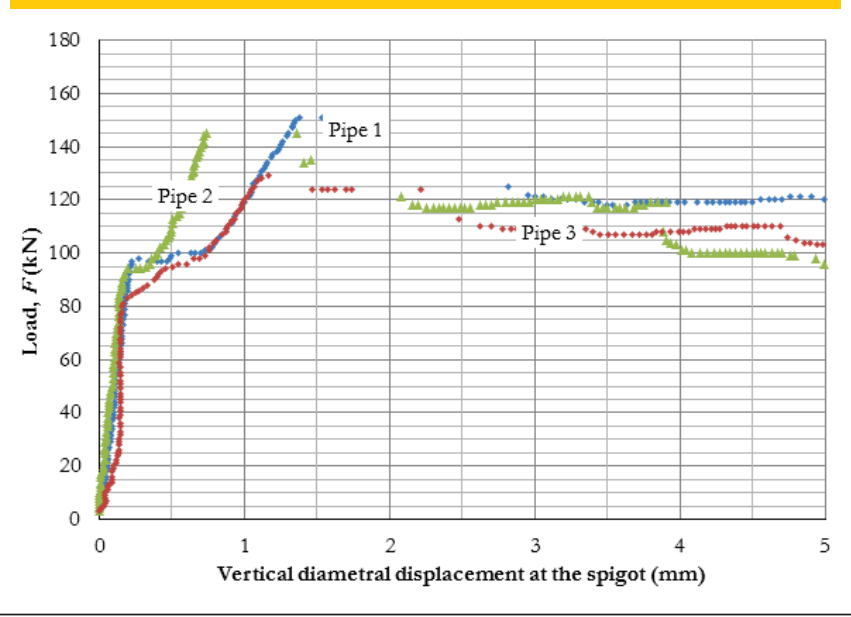

\section{Figure 13 - Load versus displacement curves obtained during crushing test of pipes with a fiber consumption of $40 \mathrm{~kg} / \mathrm{m}^{3}$ and with the diametrical displacement measured only at the spigot}

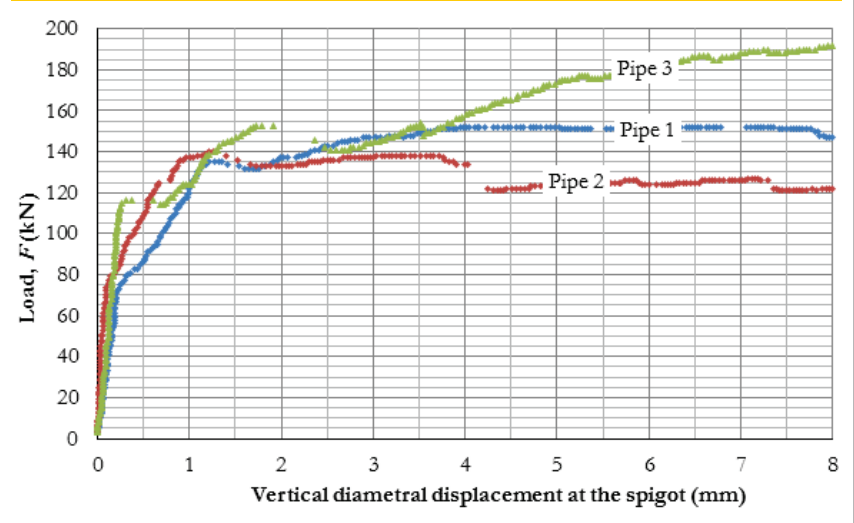

of the pipe. The difference observed in the pattern of the curves obtained in the two series of test is only attributed to geometric factors, and the characteristics of matrix and type of reinforcement have no influence on the results. So, the displacement measured at the socket will always be smaller than the one measured at the spigot. In that sense, the enlargement of the socket is the main factor influencing the pattern of the curves at the elastic region.

Due to the fact that the spigot will present a higher level of displacement, this region will present the higher level of strain and, consequently, will reach the elastic limit sooner. So, is possible to conclude that the cracking of the pipes always begins at the spigot, because the concrete reaches its elastic strain limit in this region before it occurs in the socket. In the particular case of this study it occurs around $80 \mathrm{kN}$ of loading, when the stiffness of the component was greatly reduced. As the displacements measured in the $2^{\text {nd }}$ Series were much superior to the $1^{\text {st }}$ Series due to the previously discussed loss of stiffness, it is also possible to conclude for the equivalence of the two behaviors, because both series reached close levels to residual strength. It should be emphasized that this pattern of behavior is totally consistent with the model proposed by de la Fuente et al. [5] for numerical modeling of pipes behavior during the crushing test.

An important aspect to have attention is the fact that it is impossible to carry out the standard cyclic test with pipes reinforced with $40 \mathrm{~kg} / \mathrm{m}^{3}$ of steel fibers. The difficulty occurs because of the hard-

\section{Figure 14 - Load versus displacement curves obtained during crushing test of pipes with conventional reinforcement and with the diametrical displacement measured only at the spigot}

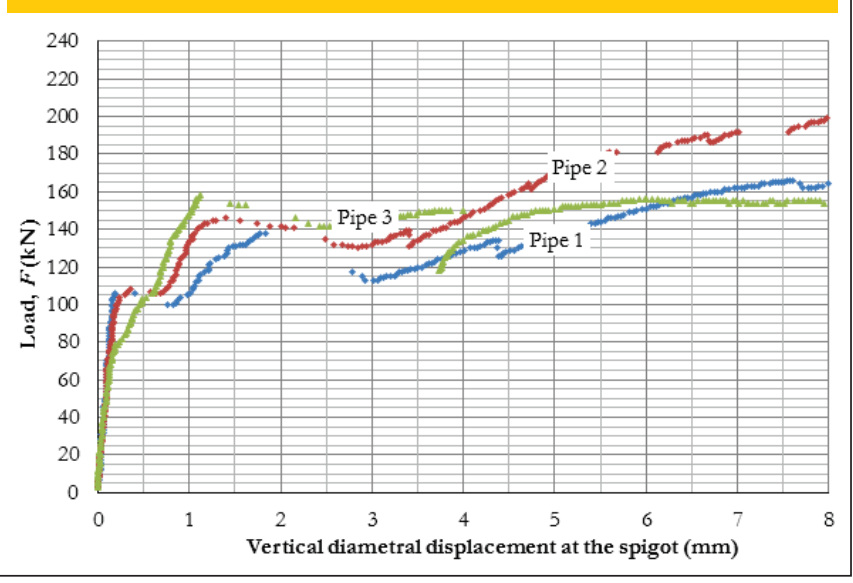

Figure 15 - Average load versus diametrical displacement curves of pipes tested in the $1^{\text {st }}$ Series

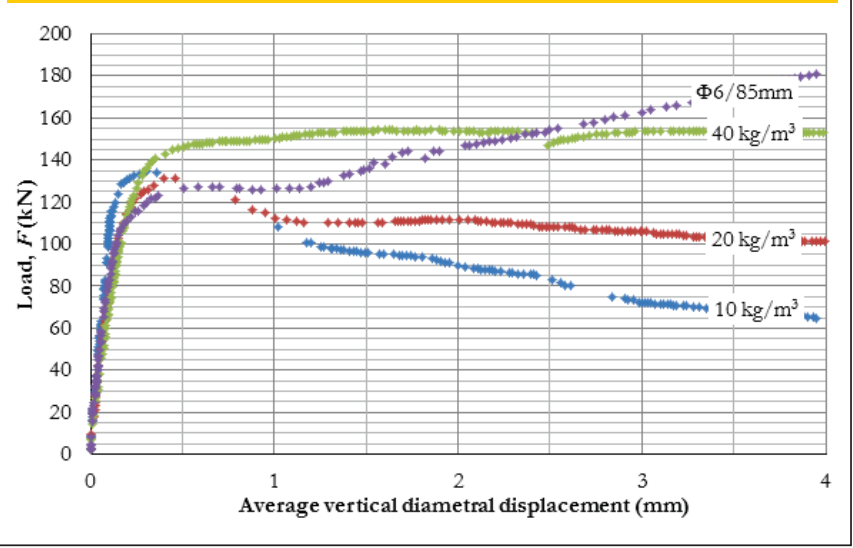




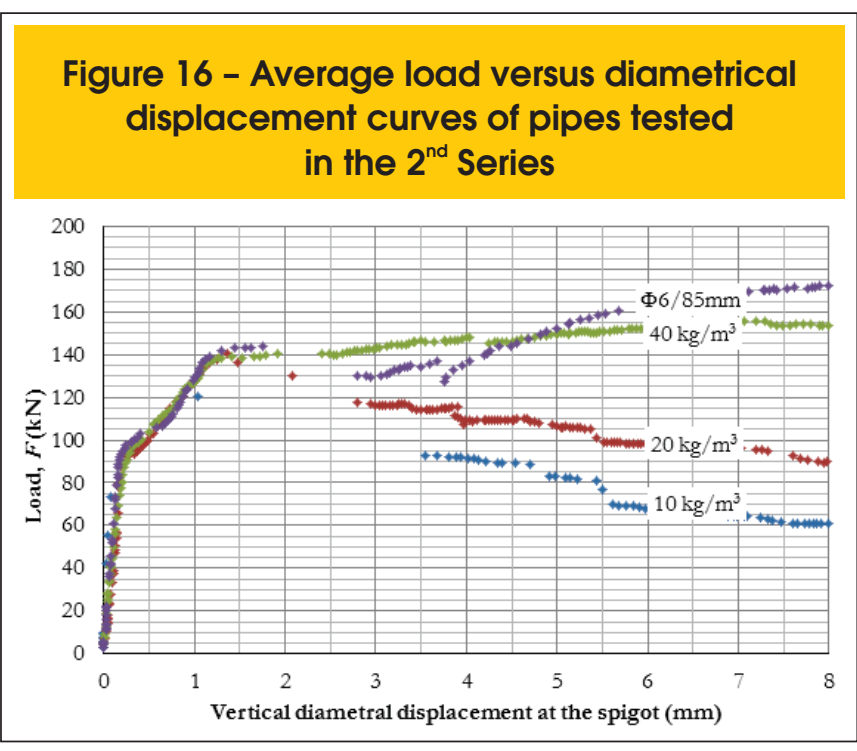

ening behavior of these pipes. In this particular case, the drop in post-peak strength at low displacements could not possible be observed. Thus there will be a high level of displacement and cracking when the unloading was done during the regular cyclical test. So, the standard procedure had the implicit concept that the FRCP should always show a softening behavior to turn possible to perform the cyclical test. Thus, the continuous measurement system using LVDTs provides greater reliability to the test in these situations. Especially when the serviceability conditions associated to the level of crack opening is considered.

There were also regions of post-peak instability in the crushing test response, similar to those observed by Figueiredo [7] when low amounts of fiber were used. This instability is provoked by the process of slipping and loss of adhesion of the fibers, in addition to possible rupture of some of them, occurring during the stress transfer from the matrix to the fibers. Furthermore, the increase in fiber content enhanced the cracking load of the matrix, corresponding to the end of the initial linear part of the curve. This, however, became clear only for the $1^{\text {st }}$ Series of pipes. In this series there was an increase of the material cohesion due to the fiber addition in to the matrix. So, there was the correction of water content in the concrete for the $2^{\text {nd }}$ Series in order to maintain the level of mobility of the matrix. In that situation, the increase in water/cement ratio gives a reduction of the matrix strength, which reduced the contribution of fiber to the elastic behavior of the component. Although this, a reduction in the load at the end of the elastic part of the curves was not observed. It occurs due to the increase in the fiber content that had improved the tensile strength capacity of concrete pipe.

It was observed that the pipes also met the requirements of the standards [2 and 4] for Class AE2. In the case of pipes with 600 $\mathrm{mm}$ nominal diameter the Brazilian [2] and European [4] standards require that the pipes have to present a load control of $36 \mathrm{kN} / \mathrm{m}$ and an ultimate load of $54 \mathrm{kN} / \mathrm{m}$. As the pipe length was $2.5 \mathrm{~m}$, it accomplish that a total load control is $90 \mathrm{kN}$ per pipe, and a ultimate load is $135 \mathrm{kN}$ per pipe.

Checking the average results presented in Figures [15] and [16], it is possible to figure out that all SBRCP exceeded both the control and ultimate load by a wide margin, especially in the $1^{\text {st }}$ Series. In this particular case, the limit of the elastic behavior reached about 130 $\mathrm{kN}$ (less than the proof load where the pipe may have a certain level of cracking). The average ultimate load was $230 \mathrm{kN}$, obtained directly from the test machine record system because it occurs when the displacement was larger than the measurement limit of the LVDTs. With these results, these pipes were about to fit the requirement of the superior class (EA3 for the Brazilian standard), which requires control and ultimate loads of $135 \mathrm{kN}$ and $202.5 \mathrm{kN}$, respectively. In the $2^{\text {nd }}$ Series, the results were slightly lower than the first one for the ultimate strength, which reached the averaged load of $174.7 \mathrm{kN}$. Since the end of the initial elastic segment was close to $90 \mathrm{kN}$, it is possible to affirm that the pipes reached the standards requirement narrowly. Anyway, it is possible to consider them as appropriate to the requirements of the standards for class EA2.

Observing the curves presented in Figures [15] and [16], it is possible to affirm that there is proximity between the behavior of SBRCP and FRCP in the first half of the load versus displacement curves. This behavior occurs in more intense way until a vertical displacement of about $0.4 \mathrm{~mm}$ and $2 \mathrm{~mm}$ for the first and $2^{\text {nd }}$ Series respectively. The FRCP with $40 \mathrm{~kg} / \mathrm{m}^{3}$ exceeded the strength loads of SBRCP until displacements of about $2.5 \mathrm{~mm}$ and $4.5 \mathrm{~mm}$ for the first and $2^{\text {nd }}$ Series respectively. It is possible to affirm that the FRCP presented a similar behavior to a superior class of SBRCP in those circumstances. The initial region of the curves could be associated to the serviceability limit state or, in other words, corresponding to the elastic or low level of cracking behavior. So, the fiber contribution will be more effective for the pipes service life than the contribution presented by the steel bars. Note that all the pipes of the $1^{\text {st }}$ Series showed the initial elastic part of the curve slightly exceeding $100 \mathrm{kN}$. With respect to this aspect, it was observed that cracking began, in all cases, at the top of the section A with values of $\boldsymbol{F}_{c r}$ around $90 \mathrm{kN}$. On the other hand, in the pipes from the $2^{\text {nd }}$ Series, it was observed that the appearance of the first cracks coincided with the change in the slope of the load-displacement curve. This change was not detected in the pipes from the $1^{\text {st }}$ Series until the springline had also cracked,

\section{Figure 17 - Comparison between the average curves measured at the socket and spigot ( $1{ }^{\text {st }}$ Series) and only at the spigot ( $2^{\text {nd }}$ Series) for FRCP with $40 \mathrm{~kg} / \mathrm{m}^{3}$ steel fibers}

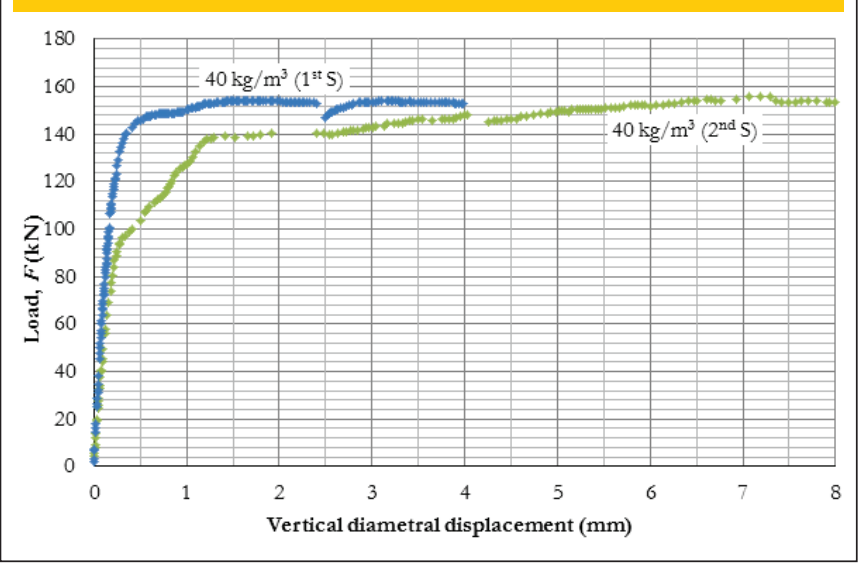


Table 3 - Maximum load and maximum post-peak load obtained in the two series of tests

\begin{tabular}{|c|c|c|c|c|c|c|c|c|c|}
\hline \multirow[b]{2}{*}{ Series } & \multirow{2}{*}{$\begin{array}{c}C_{1} \\
\left(\mathrm{~kg} / \mathrm{m}^{3}\right)\end{array}$} & \multicolumn{4}{|c|}{$F_{u}(k N)$} & \multicolumn{4}{|c|}{$F_{1.2 \mathrm{~mm}} \mathbf{Y} F_{3 \mathrm{~mm}}(\mathbf{k N})$} \\
\hline & & \multicolumn{3}{|c|}{ Individual values } & \multirow{2}{*}{$\begin{array}{c}\text { Average } \\
135\end{array}$} & \multicolumn{3}{|c|}{$\begin{array}{l}\text { Individual } \\
\text { values }\end{array}$} & \multirow{2}{*}{$\begin{array}{c}\text { Average } \\
101\end{array}$} \\
\hline \multirow{3}{*}{$1^{\text {st }}$} & 10 & 149 & 120 & $\mathrm{n} / \mathrm{a}$ & & 107 & 94 & $\mathrm{n} / \mathrm{a}$ & \\
\hline & 20 & 140 & 124 & $\mathrm{n} / \mathrm{a}$ & 132 & 118 & 102 & $\mathrm{n} / \mathrm{a}$ & 110 \\
\hline & 40 & 156 & 163 & 149 & 156 & - & - & - & - \\
\hline \multirow{3}{*}{$2^{\text {nd }}$} & 10 & 127 & 132 & 138 & 132 & 97 & 88 & 98 & 94 \\
\hline & 20 & 151 & 145 & 129 & 142 & 121 & 120 & 108 & 116 \\
\hline & 40 & 152 & 140 & 193 & 162 & - & - & - & - \\
\hline
\end{tabular}

a situation which took place when load $\boldsymbol{F}$ reached average values of $126 \mathrm{kN}, 114 \mathrm{kN}$ and $138 \mathrm{kN}$ for the pipes with $10 \mathrm{~kg} / \mathrm{m}^{3}, 20 \mathrm{~kg} /$ $\mathrm{m}^{3}$ and $40 \mathrm{~kg} / \mathrm{m}^{3}$, respectively. So, the load $\boldsymbol{F}_{c r}$ can be deduced from the load-displacement curve at the point where the first slope change takes place. On the other hand, if the measurement is performed as in the $1^{\text {st }}$ Series, this procedure would lead to values of $\boldsymbol{F}_{c r}$ on the side of insecurity, requiring a visual inspection in order to detect $\boldsymbol{F}_{c r}$, which could indicate if the control load fits the standard requirements. Since the load displacement curves obtained to the $2^{\text {nd }}$ Series of tests showed that linear region finishing when the load was about $90 \mathrm{kN}$. Thus, these pipes would be probably approved because is possible to associate this level of loading to the $\boldsymbol{F}_{c r}$.

The Brazilian standard requirements [2] for FRCP are a little broader than the European [4]. This is because, besides the load control $\left(\boldsymbol{F}_{c}\right)$ of $90 \mathrm{kN}$ and ultimate load $\left(\boldsymbol{F}_{u}\right)$ of $135 \mathrm{kN}$, common to both, the Brazilian standard requires a minimum post-peak load $\left(\boldsymbol{F}_{\text {min,pos }}\right)$ of $94,5 \mathrm{kN}$. This fact increases the importance of the post-peak residual strength of the pipes. As the tests performed for this study have not the cycle of loading, this parameter could not be determinate

\section{Figure 18 - Correlations between ultimate} load and fiber content for both series of tests

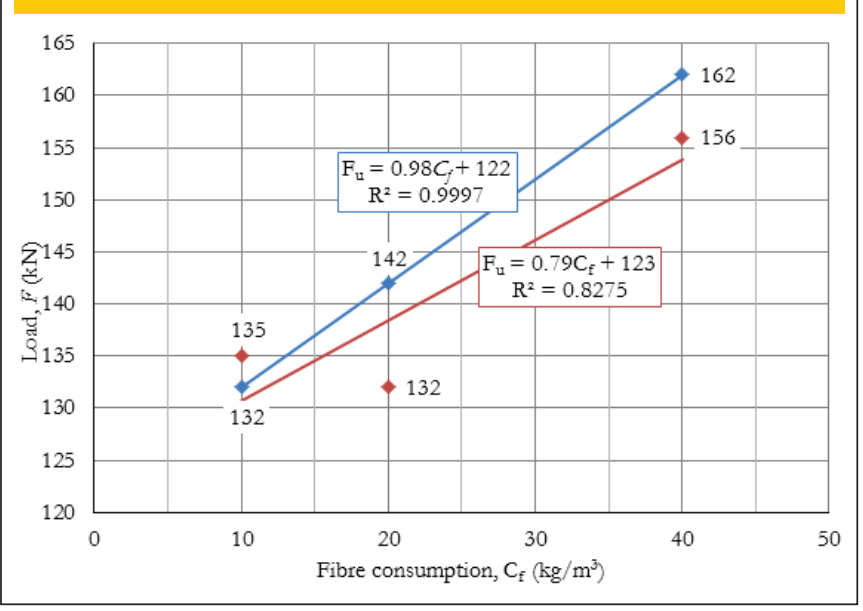

in order to evaluate if the pipes comply with the requirements. Nevertheless, a displacement level was fixed in order to determining a residual strength in the post-peak region to assess the influence of the fiber in this specific behavior of the pipe. The results presented in Table [3] and also in Figures [15] and [16] were used for the evaluation of this condition. As tests were performed continuously without re-loading cycle, it was adopted a reference displacement a little beyond post-peak instability limit for each series. Consequently, the displacements of $1.2 \mathrm{~mm}$ and $3 \mathrm{~mm}$ were adopted for determining the post-cracking load for the first and $2^{\text {nd }}$ Series, respectively. The different level of displacement was chosen due to the disparity in geometric rigidity of pipes observed when the displacement was measured only at the spigot or at the spigot and socket. That condition provides different level of displacement for the same level of cracking and post-peak residual strength.

In Figures [18] and [19] are presented the correlations between the fiber content and ultimate load $\left(\boldsymbol{F}_{u}\right)$ and the post-cracking load at

\section{Figure 19 - Correlations between fiber content and the post-peak load at the displacements of $1.2 \mathrm{~mm}$ and $3 \mathrm{~mm}$ for the first and $2^{\text {nd }}$ Series of tests respectively}

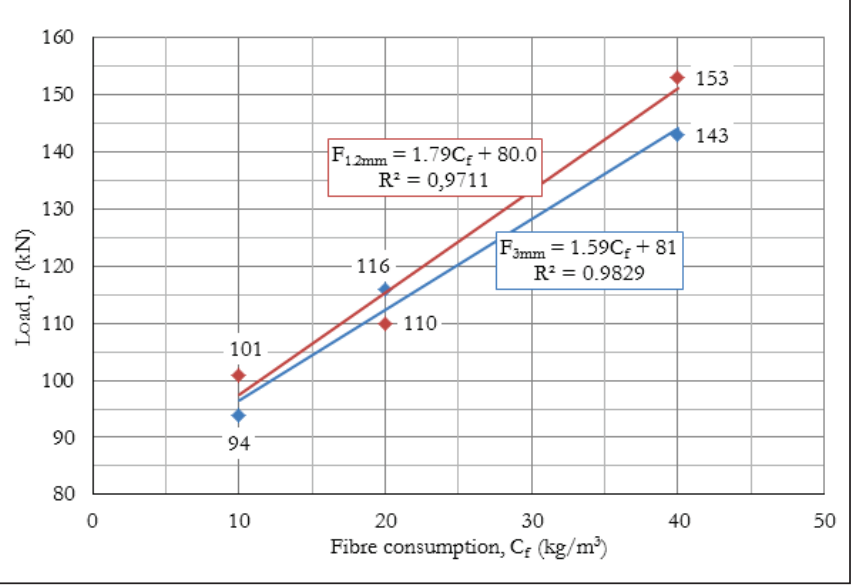


the displacements of $1.2 \mathrm{~mm}$ and $3 \mathrm{~mm}$, for the first and $2^{\text {nd }}$ Series respectively. It is possible to observe clearly that the fibers content interferes in both parameters. The linear regression between fiber content and ultimate load or post-cracking load provide good level of correlations, as shown by the coefficients of correlation. Thus, this type of curves can be used in a mix-design procedure, if the variability of the test is well known. However, the fiber mix-design in order to accomplish a required post-peak residual strength has a greater relevance when the Brazilian standard [2] is used for pipes control.

\section{Final remarks}

The performance demonstrated by the FRCP was higher than the presented by the SBRCP when they were submitted to lower levels of displacement and cracking. A similar behavior has been observed in previous studies [9]. This fact occurs because the fibers are mobilized early in the process of cracking due to their position along the wall surface of the component. Since the steel bars are eventually being placed along the neutral line, by the requirement of minimum coverage, it will demand a high level of displacement and cracking in order to mobilize their resistance. So, the behavior of FRCP with low contents of fiber is typically softening, while the pipes with rebars present a typical hardening behavior. Thus, even for low fiber consumptions, the performance of FRCP is comparable or even superior to SBRCP at low cracking and displacement level. This is particularly interesting since this is the stage of primary interest to the component application because the pipes are still in good conditions to meet the durability requirements. Moreover, in the particular case of this experimental study, the SBRCP had much better performance than the prescribed class. It also indicates that the fiber reinforcement is so efficient that approximates the behavior of FRCP to the one presented by a higher class SBRCP at the serviceability conditions.

It has been shown that the fiber content affects equally the ultimate load as the post-peak maximum load presented by the pipe in the crushing strength test. For this reason, it is important to take into account the contribution of the fiber in mix design analysis of the FRCP concerning to meeting the requirements of the ultimate and maximum post-peak load.

The results also confirmed the critical condition related to the spigot displacement in relation to the socket area. This fact shows that the component displacement measured at this position could be associated to the more demanding pipe condition in terms of displacement and crack initiation. However, this is a conservative approach concerning only to the test method, since the spigot will be protected by the follow pipe socket during use. This effect, however, is not applicable to pipes where the socket has no enlargement [2] [4]. Thus, the crushing test carried out in pipes which diametrical displacement is measured only at the spigot is very much in favor of security. Furthermore, this arrangement test proved to be much more suitable to evaluate the pipes performance. This occurs because, for pipes with higher fiber consumptions, it would not be possible to verify when the load drops to $95 \%$ of its value at low level of displacement. In that situation, the technician in charged to run the test could not observe the right moment to impose the end of the first cycle and start up the second one.

\section{Acknowledgements}

The authors of this paper wish to express their appreciation for the support received from Fermix Indústria e Comércio Ltda. and Belgo Bekaert Arames that turns possible the entire experimental work.

Likewise, Professor Antonio D. de Figueiredo wishes to thank the support provided by CAPES -Coordenação de Aperfeiçoamento de Pessoal de Nível Superior- for having awarded him the postdoctoral grant that allowed him to participate in this work.

\section{References}

[01] VIÑOLAS, V., AGUADO, A., JOSA, A. Evaluación de la sostenibilidad en tuberías de saneamiento. II Congreso UPC Sostenible 2015, Barcelona, Spain, 2009.

[02] ASSOCIAÇÃO BRASILEIRA DE NORMAS TÉCNICAS. Tubo de concreto, de seção circular, para águas pluviais e esgotos sanitários. NBR 8890, ABNT, Rio de Janeiro. 2007.

[03] FIGUEIREDO, A. D., CHAMA NETO, P. J. A nova especificação brasileira para tubos de concreto para águas pluviais e esgoto In: $49^{\circ}$ Congresso Brasileiro do Concreto CBC 2007, Instituto Brasileiro do Concreto (IBRACON), Bento Gonçalves. 2007.

[04] NBN EN1916 Concrete pipes and fittings, unreinforced, steel fibre and reinforced. Belgisch Instituut voor normalisatie (BIN), Brussel, December 2002.

[05] de la Fuente, et al. Steel fiber reinforced concrete pipes. Part 2: Numerical model to simulate the crushing test. Revista RIEM. In press.

[06] FIGUEIREDO, A.D.; CHAMA NETO, P. J.; QUINTA, M. T.; GIMENEZ, A. B. Avaliação de metodologia de ensaio de tubos de concreto reforçado com fibras para esgoto. Concreto (São Paulo). Instituto Brasileiro do Concreto (IBRACON). Vol.XXXIV, p.44 - 51, 2007.

[07] FIGUEIREDO, A.D. de. Evaluation of the test method for crushing strength of steel fiber reinforced concrete pipes. 7th International RILEM Symposium on Fibre Reinforced Concrete, Chennai, India, 2008.

[08] RAMOS, M. F. Análise experimental de tubos de concreto reforçado com fibras de aço. Campinas, UNICAMP. Universidade Estadual de Campinas. Faculdade de Engenharia Civil. Dissertação (Mestrado em Engenharia Civil). Campinas, 2002.

[09] CHAMA NETO, P.J.; FIGUEIREDO, A.D. de. Avaliação de desempenho mecânico de tubos. Revista DAE, 2008, Vol. 178, p. 34-39.

[10] de la FUENTE, A., FIGUEIREDO, A. D., AGUADO, A., MOLINS, C. CHAMA NETO, P. J. Experimentación y simulación numérica de tubos de hormigón com fibras. Materiales de Construcción, 2011, Vol. 61, $\mathrm{n}^{\circ} 302$, p. 275-288.

[11] de la FUENTE, A., AGUADO, A., MOLINS, C. Modelo numérico para el análisis no lineal de secciones prefabricadas construidas evolutivamente. Hormigón y Acero, 2008, Vol. 57, n² 247, p. 69-87.

[12] MORGAN, D.R.; MINDESS, S.; CHEN, L. Testing and Specifying Toughness for Fiber Reinforced Concrete and Shotcrete. In: Second University-Industry Work 
shop on Fiber Reinforced Concrete and Other Advanced Materials. Toronto, Canada, 1995.

Proceedings. p.29-50.

[13] LAMBRETCHS, A. Performance clases for steel fibre reinforced concrete: Be critical, 7th International RILEM Symposium on Fibre Reinforced Concrete, Chennai, India, 2008.

[14] SILVA, J. L. da ; EI DEBS, M.K. . Influência da bolsa no comportamento estrutural de tubos de concreto armado submetidos à compressão diametrical. In: $51^{\circ}$ Congresso Brasileiro do Concreto, 2009, Curitiba. 2009. p. 1-13. 